\title{
Board Structures and Managerial Ownership in Identifying the Financial Distress Likelihood
}

\author{
Saarce Elsye Hatane ${ }^{1}$, Nathalia Chandra ${ }^{2}$ and Josua Tarigan ${ }^{3}$ \\ ${ }^{1}$ Petra Christian University, Indonesia, e-mail: elsyehat@petra.ac.id \\ ${ }^{2}$ Petra Christian University, Indonesia \\ ${ }^{3}$ Petra Christian University, Indonesia
}

\begin{abstract}
This study investigates the impact of board structures and managerial ownership on the ability in preventing financial distress in the context of Indonesia and Malaysia consumer goods companies. Board structure consists of board size, composition and gender diversity. Ability in preventing in financial distress is measured by profitability (EBIT), financial expense (FE) and retained earnings (RE). This research study examines the consumer goods companies in Indonesia and Malaysia for the period of 2011 to 2015 with the total sample of 24 Indonesia companies or 120 firm-years observations and 98 Malaysia companies or 490 firm-years observations. The data examined by Partial Least Square (PLS) under the Structural Equation Model concept. The findings of this study present mixed results. Board size and board composition have significant impact on the ability in preventing financial distress in Indonesia whereas it is found insignificant in the case of Malaysia companies. On the contrary, in Indonesia, the managerial ownership has impact on the financial distress prevention, while Malaysia's result shows there is a significant impact. Additionally, this study has found that gender diversity has a significant impact on the ability in preventing financial distress in both Indonesia and Malaysia. Gender diversity also serves as moderating variable in both countries regardless of the type of moderation between both countries. Keywords: Board structure, Financial Distress, Consumer Goods Sector, Indonesia, Malaysia
\end{abstract}

\section{Introduction}

The economic and monetary crisis in $1997-1998$ has increased the interest and attention on corporate governance in Asia. It is shown on Table 1, percentage of Indonesia and Malaysia distressed companies are the highest with $49.62 \%$ and $47.21 \%$ respectively compared to Korea, Philippines, and Thailand. Distressed companies are identified as companies which had an interest coverage (the ratio of interest expenses to earnings) less than one in 1998 (Claessens, Djankov, \& Klapper, 2003). Although Indonesia and Malaysia had the highest percentage of distressed companies, but both countries had the first and third lowest percentage of number of bankruptcy companies with 3.03\% (Indonesia) and 7.09\% (Malaysia). Despite that, growth of real GDP of Indonesia in 1998 was declining $13.7 \%$ due to financial crisis. Years later, financial crisis in 2008 and financial scandals in Enron, World COM, Lehman Brothers, AIG and others have given attention to many parties including academics, researchers, regulators, policymakers and investors to evaluate corporate governance and its impact on performance and financial distress (Shahwan, 2015).

Generally, corporate governance is described as the system in which companies are directed and controlled (International Finance Corporation Advisory Sevices in Indonesia, 2014). Corporate governance is important as it is not only strengthening the business's capability in attracting investment and growing, but also developing companies to be more efficient and accountable. Corporate governance also contributes to economic and financial crisis promotion and prevention, scandal as well as transparency and accountability (Rajablu, 2016; Campbell \& Minquez-Vera, 2008). In term of agency theory, corporate governance can be used to mitigate the agency problems which occur in the company, thus the interest of both managers and shareholders can be aligned.

For this study, financial distress is defined as the lack of company's ability to cover its maturity financial obligations. There have been many research studies that have conducted the impact of corporate governance to probability of financial distress, however the findings are varied due to 
different indicators, sample, period, economic condition and others. There are several studies regarding financial distress and corporate governance have been conducted in particular countries ((Manzaneque, Priego, \& Merino, 2016), (Akhmetova \& Batomunkueva, 2014), (Donker, Santen, \& Zahir, 2009), (Kristanti, Rahayu, \& Huda, 2016), (Brédart, 2014)). Hence this study is conducted in two countries, namely Indonesia and Malaysia. Moreover, it would be interesting to learn whether the models developed for US companies also apply to foreign companies (Pindado, Rodriguesb, \& De La Torre, 2008). Furthermore, in fact, there is an increasing interest in conducting research using data from several countries at the same time (Pindado, Rodriguesb, \& De La Torre, 2008).

Table 1 Summary Statistics on Bankruptcy Fillings in 1997 and 1998

\begin{tabular}{|l|l|l|l|l|l|l|}
\hline Country & $\begin{array}{l}\text { Number of } \\
\text { observations }\end{array}$ & $\begin{array}{l}\text { Number of } \\
\text { distress } \\
\text { companies }\end{array}$ & $\begin{array}{l}\text { Distressed } \\
\text { companies } \\
\text { as \% of } \\
\text { country }\end{array}$ & $\begin{array}{l}\text { Number of } \\
\text { bankruptcies }\end{array}$ & $\begin{array}{l}\text { Number of } \\
\text { bankruptcies } \\
\text { as \% of } \\
\text { distressed } \\
\text { companies }\end{array}$ & $\begin{array}{l}\text { Real } \\
\text { GDP } \\
\text { growth } \\
\text { in 1998 } \\
(\%)\end{array}$ \\
\hline Indonesia & 133 & 66 & 49.62 & 2 & 3.03 & -13.7 \\
\hline Korea & 282 & 116 & 41.14 & 26 & 22.41 & -5.8 \\
\hline Malaysia & 627 & 296 & 47.21 & 21 & 7.09 & -6.7 \\
\hline Philippines & 68 & 20 & 29.41 & 1 & 5.00 & -0.5 \\
\hline Thailand & 362 & 146 & 40.33 & 33 & 22.60 & -9.1 \\
\hline
\end{tabular}

Source: (Claessens, Djankov, \& Klapper, 2003).

Indonesia

in comparison with Malaysia

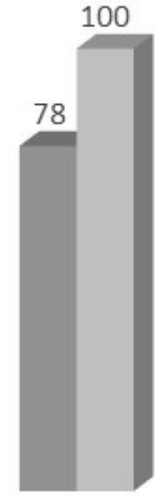

Power Distance

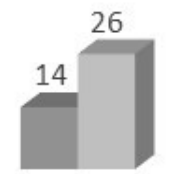

Individualism

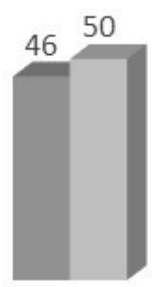

Masculinity
Uncertainty

Avoidance

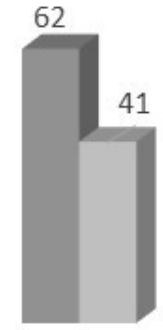

Long Term Orientation

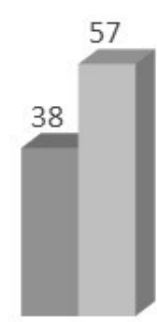

Indulgence

- Indonesia Malaysia

Figure 1 Comparison of Hofstede Score in Indonesia and Malaysia. Source: (Hofstede, 2017)

This study chooses Indonesia and Malaysia listed companies in consumer goods sector as the sample due to some reasons. First, there is high competitiveness between companies in manufacturing industry particularly in consumer goods sector. Not only that, development of this industry and sector is very rapid. Manufacturing industry contributes $20.51 \%$ as the largest contributor to economy in Indonesia (Badan Pusat Statistik, 2017) whereas manufacturing industry in Malaysia is the second largest with 23\% (Department of Statistics Malaysia, 2017) Furthermore, the projection of Asian retails sales in 2018 which is conducted by PWC (2015) indicates that there will be $60 \%$ of global 
consumer expenditure in food, beverage and tobacco category due to increase in income and shift in consumer preferences. Market demand growth in Indonesia and Malaysia for food, beverages and tobacco is predicted to be 5\% and 5.1\% respectively in 2018 (PWC, 2015) compared to 3.5\% and $4.5 \%$ respectively in 2011 .

Moreover, there is a study about the effectiveness of corporate governance in Asia (McGee, 2008) which emphasizes on objectivity, compliance, fairness and other points shows that Malaysia reached 77.3 point out of 100, which is the total point, compared to Indonesia, Thailand and Vietnam (McGee, 2008). It shows that Malaysia has better corporate governance compared to the other countries. Third, Indonesia and Malaysia are similar in terms of national culture which is measured by Hofstede cultural dimension. Figure 1 describes that both Indonesia and Malaysia have high power distance, low uncertainty avoidance, low individualism and low preference for avoiding uncertainty. For the masculinity, Indonesia is considered low whereas Malaysia's score is 50 which the preference of this dimension can't be determined. The observed periods in year 2011 until 2015 are chosen as those are the periods when Indonesia and Malaysia, as part of ASEAN and included in the major countries in the ASEAN region, were preparing themselves to carry out the ASEAN Economic Community (AEC) agreement.

Hence based on above description, this research study inspects four research problems. This study examines the influence of board structures, which comprises of board size and board composition; managerial ownership; and gender diversity on the ability in preventing financial distress. In addition, this study investigates the moderating influence of gender diversity towards the relationship of board structures and the financial distress likelihood. There are remaining four sections in this research study. The second section explains literature review of the variables together with the theories and hypothesis. The third section describes the research methodology. The fourth section is about the result of the research, analysis, and discussion. The last section provides the summary of the research findings as well as suggestions for future research.

OECD (2004) describes corporate governance is a set of relationships between a company's management, its board, its shareholders and other stakeholders. Additionally, World Bank (2010) stated that corporate governance refers to "the structure and processes for the direction and control of companies." Corporate governance has a key role in business success or failure and company's accountability and transparency (Rajablu, 2016). Good corporate governance contributes to sustainable economic development by increasing the company's performance (World Bank, 2010). In addition, corporate governance can help to reduce agency problems. The conflict of interest between management, shareholders, investors and debt holders are more serious and intense in financial distress situation compared to normal condition (Donker, Santen, \& Zahir, 2009).

Financial crisis in 1997-1998 that has brought a dramatic, adverse impact on Indonesia's social, economic and political environment (International Finance Corporation Advisory Sevices in Indonesia, 2014). National Committee on Corporate Governance (KNKCG) has been established in 1999 and was then changed to National Committee on Governance (KNKG) in 2004 (International Finance Corporation Advisory Sevices in Indonesia, 2014). Indonesia implements two - tier system in which the board of directors (BOD) and board of commissioners (BOC) are separated. BOC has the responsibility in overseeing and providing advice to BOD whereas BOD is responsible for the day-to-day of the company's management (International Finance Corporation Advisory Services in Indonesia, 2014).

Malaysia was strong in governance guidelines compared to other Asian countries and had made some efforts to ensure effective corporate governance practices in its public listed companies even before the financial crisis in 1997-1998 (Kamardin \& Haron, 2011; Wahab, Pitchay, \& Ali, 2015). Additionally, the emphasis on corporate governance practices were particularly being highlighted by Malaysia government in the aftermath of financial crisis in order to boost investors' confidence. Malaysian Code on Corporate Governance (MCCG) is a key document in Malaysia's corporate governance framework and has contributed significantly in increasing the corporate governance 
standards of Malaysian listed companies (Securities Commission Malaysia, 2016). MCCG was first issued in March 2000 and later was revised in 2007 and 2012 (Securities Commission Malaysia, 2012). Malaysia adopts one - tier system or unitary board system in their corporate governance system which the responsibility of board of directors are about management oversight roles and performance evaluation roles (Kamardin \& Haron, 2011). This research study would like to examine the impact of board structure, managerial ownership and gender diversity to the ability in preventing financial distress as a dependent variable with gender diversity is also as moderating variable.

Financial distress begins when the company cannot meet its scheduled payments or when cash flow projection indicates that the company will soon be unable to cover its obligations (Brigham \& Daves, 2007). Financial distress is also defined as the lack of company's ability to cover its maturity financial obligations (Pindado, Rodriguesb, \& De La Torre, 2008). The study reports the factors are mainly financial factors $(47.3 \%)$, economic factors $(37.1 \%)$, neglect, disaster and fraud (14\%) and other factors (1.6\%) (Brigham \& Daves, 2007). According to Pindado, et al. (2008), financial distress companies that are considered are those that meet some of the following criteria:

1. Its earnings before interest and taxes depreciation and amortization (EBITDA) are lower than its financial expenses for two consecutive years; and/or

2. A fall in its market value appears between 2 consecutive periods.

As this research study applies the concept of business failure by Pindado, Rodriguesb, \& De La Torre (2008), the explanatory variables for financial distress will be earning before interest (EBIT), financial expense $(\mathrm{FE})$ and retained earnings $(\mathrm{RE})$. The selection of explanatory variables is relied on financial theory (Pindado, Rodriguesb, \& De La Torre, 2008). The original formula of FE FE $t_{t} / \mathrm{RTA}_{\mathrm{t}-1}$ is reversed for the purpose of this study. Profitability, financial expense and retained earnings will be calculated using EBIT $/ \mathrm{RTA}_{t-1}, \mathrm{RTA}_{\mathrm{t}-1} / \mathrm{FE}_{\mathrm{t}}, \mathrm{RE}_{t} / \mathrm{RTA}_{\mathrm{t}-1}$ as the instrument of measure respectively. EBIT $_{t} /$ RTA $_{t-1}$, is measured by earnings before interest and taxes id divided by total assets at the beginning period. $\mathrm{RTA}_{t-1} / \mathrm{FE}_{t}$ is measured by total assets at the beginning period divided by financial expense. Lastly, $\mathrm{RE}_{t} / \mathrm{RTA}_{\mathrm{t}-1}$ is measured by retained earnings divided by total assets at the beginning period.

Board Size. In agency framework, board has functions to resolve agency problems between managers and shareholders by setting compensation and replacing managers that do not create value for shareholders (Fama \& Jensen, 1983). The quality of managerial monitoring and controlling can be determined by the board size (Lakshan and Wijekoon, 2012). Small board size may be better in non - financial distressed companies due to free-rider problems and easier coordination (Yermack, 1996). Based on agency theory, large board size also increases the disciplinary control over the CEO and management. Large board size may have more business contacts that can raise the help in facing the financial distress situation through strategic alliances or partners to emerge from financial distress (Fich \& Slezak, 2008; Lakshan and Wijekoon, 2012). As for resource dependence perspective, large board size means the more connections or external contacts and diversification of skills which can protect the company from the adversity in financial distress situation (Manzaneque, et al., 2016). Board size is measured by "the total numbers of members in the boards."

Board Composition. Independent directors represent better shareholder's interest compared to inside directors or non - independent directors in the distress situation (Fich \& Slezak, 2008). Further, independent boards may be more willing to remove ineffective executives before a crisis reaching the point of corporate bankruptcy (Daily, Dalton, \& Cannella Jr, 2003). Independent director may also have more different skills and knowledge to give them perspective to solve the crisis (Fich \& Slezak, 2008). It is in line with resource dependency theory which states that independent directors can bring in knowledge and expertise, thus it minimizes the uncertainty of the environment. Board composition is measured by "the number of independent board members divided by the total number of board members" (Manzaneque, Priego, \& Merino, 2016; Akhmetova \& Batomunkueva, 2014). Based on above description, the first hypothesis can be expressed as follow.

H1: Board structure has an impact to the ability in preventing financial distress. 
The monitoring and control function of the board can be improved through large managerial ownership (Akhmetova \& Batomunkueva, 2014; Salloum, Bouri, \& Schmitt, 2013), thus it also can reduce agency cost. Fich \& Slezak (2008) conclude that large board ownership can minimize the bankruptcy hazard. Incentive mechanism including board ownership can be an effective incentive to align the interest of managers and shareholders (Donker, Santen, \& Zahir, 2009). Based on agency theory, board directors who have ownership in the company will not make decisions that might potentially affect his wealth (Jensen, 1993; Jensen \& Meckling, 1976). Fich and Slezak (2008) study shows negative relationship between share ownership of the board with the likelihood of business failure. Li, et al. (2008), Wang and Deng (2006), Donker, et al. (2009) and Manzaneque, et al. (2016) concludes that there is a negative relationship between managerial ownership and financial distress. Managerial ownership is measured by "the ratio of shares owned by the board to total outstanding ordinary shares” (Manzaneque, Priego, \& Merino, 2016; Akhmetova \& Batomunkueva, 2014).

H2: Managerial ownership has an impact to the ability in preventing financial distress.

Gender diversity which comprises of men and women in board is a superior and tougher monitoring (Adams \& Ferreira, 2004). Women can add value by giving different perspectives, experiences and opinions on the boardrooms (Adams \& Ferreira, 2004). In addition, gender diversity has positive effect on company's performance who have weak governance as measure by their abilities to resist takeovers (Adams \& Ferreira, 2009). Aside from all of those, Kristanti, et al. (2016) proves that there is negative relationship between gender diversity with the financial distress. In contrary, research study of Santen \& Donker (2009) shows that gender diversity and financial distress have no relationship. Gender diversity is measured by "number of women on board divided by total members on board" (Kristanti, Rahayu, \& Huda, 2016; Carter, Simkins, \& Simpson, 2003; Darmadi, 2013). Based on above description, the third and fourth hypothesis can be expressed as.

H3: Gender diversity has an impact to the ability in preventing financial distress.

H4: Gender diversity has an impact as a moderating variable to the ability in preventing financial distress.

\section{Research Methodology}

Board structures, managerial ownership and gender diversity are the independent variables. Gender diversity also as moderating variable. Ability in preventing financial distress as dependent variable. This research uses secondary data which are taken from annual reports and Bloomberg. The population are consumer goods listed companies in Indonesia Stock Exchange (IDX) and Bursa Malaysia for the period of 2011 to 2015. This research study uses purposive sampling technique, thus there are four chosen criteria to determine the sample of the research which are as follows. For Indonesia companies, the company is listed in Indonesia Stock Exchange (IDX) in consumer goods sector. For Malaysia companies, the company is listed in Bursa Malaysia in consumer products sector. All Indonesia and Malaysia listed companies had Initial Public Offering (IPO) before 2010 and published a complete annual report for the period of 2011 - 2015, and all Indonesia and Malaysia listed companies must have financial expenses.

120 observations (firm-year companies) of Indonesia listed companies and 490 observations (firmyear companies) of Malaysia listed companies were identified as the unit analysis with complete corporate governance and financial data. Hence, the total unit of analysis in this research is 610 firmyear companies (122 companies for 5 years) in consumer goods sector listed in Indonesia Stock Exchange and consumer products sector listed in Bursa Malaysia for the five-year period of 2011 to 2015.

As this research study used structural equation modeling (SEM), the SEM analysis is carried out using statistic software, named WarpPLS, which is the development of PLS is a graphical user interface statistic software for both variance-based and factor-based structural equation modelling (SEM) by combining both partial least squares (PLS) and factor-based methods (Kock, 2015). 
Furthermore, WarpPLS is equipped with the analysis of moderating variable with the interaction variable approach so it will be easier for the users (Solimun, 2017).

\section{Result and Discussion}

Using WarpPLS software, model analysis used in testing the hypotheses is shown below

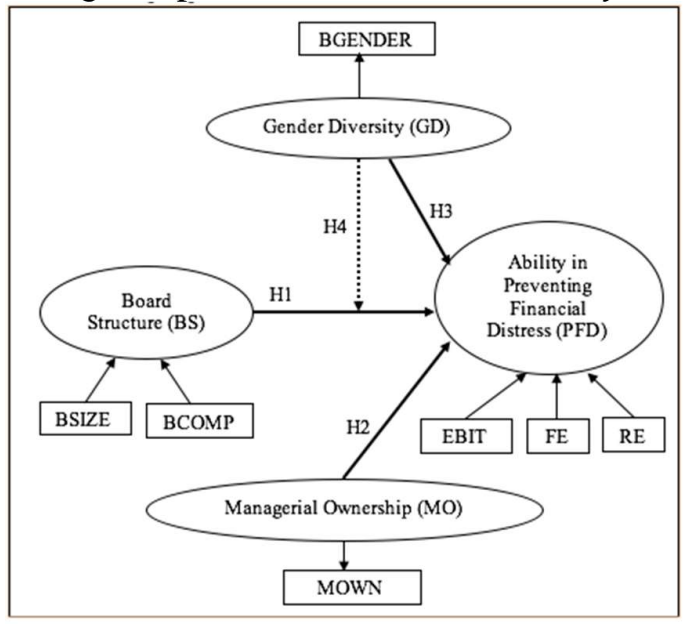

Figure 2. Model Analysis

Based on the model analysis, the formula is expressed as below:

$\mathrm{PFD}=\alpha+\beta_{1} \mathrm{BS}+\beta_{2} \mathrm{MO}+\beta_{3} \mathrm{GD}+\beta_{4} \mathrm{GD} \times \mathrm{BS}$

Where: $\mathrm{BSIZE}=$ Board size; $\mathrm{BCOMP}=$ Board composition

MOWN $=$ Managerial ownership; BGENDER $=$ Gender diversity; EBIT $=$ Earnings before interest and taxes - Profitability; FE = Financial expense; RE = Retained earnings

For Indonesia, the calculation for each independent variable is separated between the BOD and BOC (i.e. BSIZE is separated into BODSIZE and BOCSIZE).

As it shown in Table 2, all Indonesia consumer goods companies had complied with the regulation of UU PT. No. 40 year 2007 article 92 paragraph (4) that states “...listed company must have at least 2 (two) members of board of directors". This statement is also the same with statement on chapter 2 article 2 paragraph (1) of Indonesia Financial Services Authority (Number: 33/POJK.04/2014) about Board of Directors and Board of Commissioners in Public Companies. In addition, BOCSIZE of Indonesia consumer goods companies had also complied with Under UU PT. No. 40 year 2007, article 108 paragraph (3) that states board of commissioners should consist of at least 1 (one) members or more in board of commissioners. On the other hand, Malaysia corporate governance code (MCCG) does not mentioned the exact number of board members nor set the maximum number of board directors in the company's boards for listed companies (Securities Commission Malaysia, 2012). However, the number of member(s) on company's board should be appropriate for company's benefit and its business (Securities Commission Malaysia, 2012). 
Table 2. Descriptive of Indicators-Indonesia

\begin{tabular}{|l|c|c|c|c|}
\hline \multicolumn{1}{|c|}{ Indicators } & Min & Max & Mean & Std. Dev \\
\hline BOD Size & 3.00 & 12.00 & 5.21 & 2.23 \\
\hline BOC Size & 2.00 & 9.00 & 4.35 & 1.69 \\
\hline BOD Comp & 0.00 & 0.40 & 0.07 & 0.12 \\
\hline BOC Comp & 0.00 & 0.80 & 0.40 & 0.12 \\
\hline BOD Mown & 0.00 & 0.23 & 0.02 & 0.06 \\
\hline BOC Mown & 0.00 & 0.02 & 0.00 & 0.00 \\
\hline BOD Gender & 0.00 & 0.67 & 0.12 & 0.17 \\
\hline BOC Gender & 0.00 & 0.67 & 0.14 & 0.21 \\
\hline EBIT & -0.15 & 0.98 & 0.17 & 0.19 \\
\hline FE & 9.98 & 41405.45 & 565.67 & 3779.72 \\
\hline RE & -1.45 & 1.04 & 0.26 & 0.40 \\
\hline
\end{tabular}

Source: Author's compilation

Table 3. Descriptive of Indicators-Malaysia

\begin{tabular}{|l|c|c|c|c|}
\hline \multicolumn{1}{|c|}{ Indicators } & Min & Max & Mean & Std. Dev \\
\hline BOD SIZE & 4.00 & 17.00 & 7.19 & 1.87 \\
\hline BOD COMP & 0.29 & 0.80 & 0.45 & 0.12 \\
\hline BOD MOWN & 0.00 & 0.64 & 0.16 & 0.19 \\
\hline BOD GENDER & 0.00 & 0.50 & 0.11 & 0.13 \\
\hline EBIT & -0.87 & 0.96 & 0.08 & 0.14 \\
\hline FE & 17.10 & 296107.44 & 3766.52 & 23467.27 \\
\hline RE & -1.17 & 1.39 & 0.25 & 0.30 \\
\hline
\end{tabular}

Source: Author's compilation

At the same time in Malaysia, the range of BODCOMP is from $28.6 \%$ to $80 \%$ with the mean value of $45 \%$ which are slightly higher than Indonesia. The range of BODCOMP Malaysia is also higher than range of BODCOMP in Indonesia which are from $0 \%$ to $40 \%$. The maximum BODCOMP in Malaysia is two times higher compared to Indonesia BODCOMP. On contrary, the maximum BODCOMP in Malaysia is the same with maximum value of BOCCOMP in Indonesia.

The range of BODMOWN are $0 \%$ to $23 \%$ (BOD - Indonesia), $0 \%$ to $2 \%$ and $0 \%$ (BOC - Indonesia) to $63.71 \%$ (Malaysia). The minimum BODMOWN in Malaysia has the same value with the minimum BODMOWN and BOCMOWN in Indonesia which are $0 \%$. It indicates that many board of directors in Malaysia and Indonesia companies did not hold any share ownership. Maximum of BODMOWN in Malaysia is higher compared to BODMOWN and BOCMOWN in Indonesia. The mean of BODMOWN in Malaysia (15.9\%) are higher compared to average BODMOWN in Indonesia (2\%). For board of director gender diversity (BODGENDER), the range is from $0 \%$ to $67 \%$ with mean and standard deviation of $12 \%$ and $17 \%$ respectively. Board of commissioners' gender diversity has the same minimum value of $0 \%$ and maximum value of $67 \%$ as BODGENDER. BOCGENDER mean is $14 \%$ and standard deviation is $21 \%$. The maximum and mean of gender diversity in BOC is a little bit higher than in BOD. It shows that proportion of women on board is slightly higher on BOC compared to on BOD. In Malaysia, BODGENDER has minimum value of $0 \%$ and maximum value of $50 \%$ with mean of $11.12 \%$. When average of BODGENDER in Malaysia is compared with BODGENDER in Indonesia, it shows that proportion of women on board of directors in Malaysia is slightly lower.

Lastly, the average value of EBIT in Indonesia (0.17) is higher compared to Malaysia (0.08). On the contrary, Malaysia has higher average FE value of 3766.5167 compared to Indonesia which has 
average FE value of 565.67. On the other hand, the average values of RE in both Indonesia and Malaysia are quite similar with value of 0.26 and 0.25 respectively.

Both Indonesia and Malaysia data show that the models have passed all criteria of goodness of fit test. This indicates that both models can be used in this research study as both models are considered to be fit. Table 4 presents the result of model fit and quality indices of Indonesia and Malaysia consumer goods listed companies.

For Indonesia, all indicators of board structure show positive contribution, except BODCOMP. Weight indicator of BODCOMP shows negative contribution to the variable of board structure which means the higher number of independent board of directors on board, the lower board structure (BS) value it has. On contrary, the strongest indicator of board structure variable in Indonesia is BODSIZE with weight of 0.475 . The positive sign means that the larger number of board of directors who sit on the board, the higher overall board structure value it has. It is in accordance with resource dependency theory. Resource dependency theory explained that larger board size gives many advantages, such as there will be different knowledge, expertise, experiences and contacts that the company can benefit from in achieving the business objectives through company's capability in getting resources and information from directors (Isidro \& Sobral, 2014; Pearce \& Zahra, 1992; Fich \& Slezak, 2008).

Table 4. Model Fit and Quality Indices - Indonesia and Malaysia

\begin{tabular}{|c|c|c|c|}
\hline Model fit \& Quality Indices & Fit Criteria & Indonesia Result & $\begin{array}{c}\text { Malaysia } \\
\text { Result }\end{array}$ \\
\hline Average Path Coefficient (APC) & $\mathrm{p}<0.05$ & $0.154(\mathrm{P}=0.021)$ & $\begin{array}{l}0.142 \\
\mathrm{P}<0.001\end{array}$ \\
\hline Average R-squared (ARS) & $\mathrm{p}<0.05$ & $0.178(\mathrm{P}=0.011)$ & $\begin{array}{l}0.132 \\
\mathrm{P}<0.001 \\
\end{array}$ \\
\hline $\begin{array}{lll}\begin{array}{l}\text { Average } \\
\text { (AARS) }\end{array} & \text { adjusted } & \text { R-squared } \\
\end{array}$ & $\mathrm{p}<0.05$ & $0.149(\mathrm{P}=0.023)$ & $\begin{array}{l}0.125 \\
\mathrm{P}<0.001\end{array}$ \\
\hline Average Block VIF (AVIF) & Acceptable if $\leq 5$, ideally $\leq 3.3$ & 1.178 & 1.106 \\
\hline $\begin{array}{l}\begin{array}{l}\text { Average full collinearity } \\
\text { (AFVIF) }\end{array} \\
\end{array}$ & Acceptable if $\leq 5$, ideally $\leq 3.3$ & 1.315 & 1.03 \\
\hline \multirow{3}{*}{ Tenenhaus GoF (GoF) } & Small $\geq 0.1$ & \multirow{3}{*}{0.29} & \multirow{3}{*}{0.282} \\
\hline & Medium $\geq 0.25$ & & \\
\hline & Large $\geq 0.36$ & & \\
\hline Sympson's paradox ratio (SPR) & $\begin{array}{l}\text { Acceptable if } \geq 0.7, \text { ideally }= \\
1\end{array}$ & 1 & 1 \\
\hline 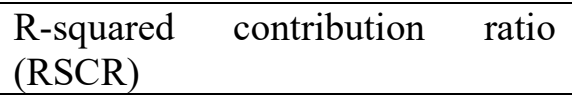 & $\begin{array}{l}\text { Acceptable if } \geq 0.9, \text { ideally }= \\
1\end{array}$ & 1 & 1 \\
\hline Statistical suppression ratio (SSR) & Acceptable if $\geq 0.7$ & 1 & 1 \\
\hline $\begin{array}{l}\text { Nonlinear bivariate causality } \\
\text { direction ratio (NLBCDR) }\end{array}$ & Acceptable if $\geq 0.7$ & 1 & 0.875 \\
\hline
\end{tabular}

Source: Author's compilation

On the other hand, for Malaysia case, board of director size (BODSIZE) and board of director composition (BODCOMP) have the same weight contribution to board structure variable with value of 0.900 . Therefore, it means that board size is as important as board composition regarding their contribution to board structure variable in Malaysia. However, board of director composition in Malaysia has different sign compared to Indonesia case. 
Table 5. Weight Indicators - Indonesia

\begin{tabular}{|l|c|c|c|}
\hline \multicolumn{1}{|c|}{ Indicator } & Weight Indicator & P value & VIF \\
\hline BODSIZE & 0.475 & $<0.001$ & 1.509 \\
\hline BOCSIZE & 0.384 & $<0.001$ & 1.274 \\
\hline BODCOMP & -0.185 & 0.018 & 1.038 \\
\hline BOCCOMP & 0.393 & $<0.001$ & 1.242 \\
\hline BODMOWN & 0.692 & $<0.001$ & 1.002 \\
\hline BOCMOWN & 0.692 & $<0.001$ & 1.002 \\
\hline BODGENDER & 0.636 & $<0.001$ & 1.059 \\
\hline BOCGENDER & 0.636 & $<0.001$ & 1.059 \\
\hline EBIT & 0.549 & $<0.001$ & 1.134 \\
\hline FE & 0.31 & $<0.001$ & 1.02 \\
\hline RE & 0.562 & $<0.001$ & 1.143 \\
\hline BODGENDER x BODSIZE & 0.338 & $<0.001$ & 6.798 \\
\hline BODGENDER x BOCSIZE & 0.046 & 0.304 & 1.756 \\
\hline BODGENDER x BODCOMP & -0.167 & 0.029 & 1.423 \\
\hline BODGENDER x BOCCOMP & 0.212 & 0.008 & 2.34 \\
\hline BOCGENDER x BODSIZE & 0.344 & $<0.001$ & 6.486 \\
\hline BOCGENDER x BOCSIZE & 0.089 & 0.161 & 1.658 \\
\hline BOCGENDER x BODCOMP & -0.145 & 0.051 & 1.264 \\
\hline BOCGENDER x BOCCOMP & 0.228 & 0.005 & 1.827 \\
\hline
\end{tabular}

Source: Author's compilation

The most important indicator of preventing financial distress in Indonesia and Malaysia are RE with weight of 0.562 and 0.617 respectively. However, both EBIT and RE in Indonesia and Malaysia are the strongest compared to its FE weight. This mean that those two indicators of EBIT and RE are important in forming its latent variable. As both countries have significantly lower value of FE, it indicates that this indicator is not as important in forming the variable. Further, weight of EBIT and $\mathrm{RE}$ in Indonesia are 0.549 and 0.562 respectively whereas the weight of EBIT and RE in Malaysia are 0.611 and 0.617 respectively. Both weight of EBIT and RE in Indonesia and Malaysia do not show big difference.

In measuring total effect, the direct effect is taken into consideration. The total effect of board structure (BS) to the ability in preventing financial distress (PFD) in Indonesia is significantly higher at $6.6049 \%$ whereas in Malaysia it is very low at only $0.2116 \%$. The relationship between BS and PFD in Indonesia represents the strongest effect compared to relationship of other latent variables with PFD. In addition, the effect of BS to PFD in Indonesia is significant at $\alpha=5 \%$ while the relationship of BS to PFD is not significant in Malaysia as the $p$ value is more than significant level of $\alpha=5 \%$ and $\alpha=10 \%$.

Table 6. Weight Indicators - Malaysia

\begin{tabular}{|l|c|c|c|}
\hline \multicolumn{1}{|c|}{ Indicators } & Weight Indicator & P-value & VIF \\
\hline BODSIZE & 0.9 & $<0.001$ & 1.171 \\
\hline BODCOMP & 0.9 & $<0.001$ & 1.171 \\
\hline BODMOWN & 1 & $<0.001$ & 0 \\
\hline BODGENDER & 1 & $<0.001$ & 0 \\
\hline EBIT & 0.611 & $<0.001$ & 1.116 \\
\hline FE & 0.049 & 0.127 & 1.003 \\
\hline RE & 0.617 & $<0.001$ & 1.118 \\
\hline BODGENDER x BODSIZE & 0.971 & $<0.001$ & 1.283 \\
\hline BODGENDER x BODCOMP & 0.971 & $<0.001$ & 1.283 \\
\hline
\end{tabular}

Source: Author's compilation 
On the other hand, the total effect result of managerial ownership (MO) to the ability in preventing financial distress (PFD) is in contrast with the total effect result of board structure (BS) to ability in preventing financial distress (PFD). The total effect between MO and PFD in Malaysia has the highest effect compared to the relationship of other latent variables with PFD. On the contrary, the total effect value between MO and PFD in Indonesia has a smallest effect at only $0.2704 \%$. Moreover, the relationship between MO and PFD in Indonesia is not significant as the p value is more than the significant level of $\alpha=5 \%$ and $\alpha=10 \%$. In case of Malaysia, the relationship of MO and PFD is significant at $\alpha=5 \%$.

Next is the total effect of gender diversity (GD) to the ability in preventing financial distress (PFD). The relationship between GD and PFD in both Indonesia and Malaysia cases represent the second strongest effect among other latent variables. Total effect results of GD to PFD in Indonesia and Malaysia are $2.5921 \%$ and $3.24 \%$ respectively. Further, the relationship of GD and PFD in both countries have significant effect as the $p$ value is less than significant level of $\alpha=5 \%$.

Lastly, the total effect of gender diversity (GD) as a moderating variable in Indonesia is $2.0736 \%$ whereas in Malaysia it is only at $0.3721 \%$. The total effect of GD as moderating variable in both Indonesia and Malaysia represent the third strongest effect among other latent variables. Although it is similar as third strongest effect, the total effect value of Malaysia is much lower compared to the value of Indonesia. Similar to the relationship of GD to PFD, the effect of GD as moderating variable to the relationship of BS to PFD in both Indonesia and Malaysia sample are significant, however it is at significant level of $\alpha=10 \%$

Table 7. Results Summary

\begin{tabular}{|c|c|c|c|c|c|c|}
\hline \multirow{2}{*}{ Country } & \multicolumn{3}{|c|}{ Type of Variable } & \multirow{2}{*}{$\begin{array}{c}\text { Type of Effect } \\
\text { Total Effect }\end{array}$} & \multirow[t]{2}{*}{ Explanation } & \multirow{2}{*}{$\begin{array}{c}\text { Hypothesis } \\
\text { Accept/Reject }\end{array}$} \\
\hline & Independent & Moderating & Dependent & & & \\
\hline \multirow{4}{*}{ Indonesia } & $\begin{array}{l}\text { Board Structure } \\
\text { (BS) }\end{array}$ & - & $\begin{array}{c}\text { Ability in Preventing } \\
\text { Financial Distress (PFD) }\end{array}$ & $\begin{array}{c}0.257 \\
\text { ( } p \text { value }=0.002)\end{array}$ & $\begin{array}{c}\text { BS has positive impact on } \\
\operatorname{PFD}(\alpha=5 \%)\end{array}$ & $\mathrm{Hl}$ is accepted \\
\hline & $\begin{array}{c}\text { Managerial } \\
\text { Ownership (MO) }\end{array}$ & - & $\begin{array}{c}\text { Ability in Preventing } \\
\text { Financial Distress (PFD) }\end{array}$ & $\begin{array}{c}-0.052 \\
(\mathrm{p} \text { value }=0.283)\end{array}$ & MO has no impact on PFD & $\mathrm{H} 2$ is rejected \\
\hline & $\begin{array}{l}\text { Gender Diversity } \\
\text { (GD) }\end{array}$ & - & $\begin{array}{c}\text { Ability in Preventing } \\
\text { Financial Distress (PFD) }\end{array}$ & $\begin{array}{c}0.161 \\
(\mathrm{p} \text { value }=0.034)\end{array}$ & $\begin{array}{c}\text { GD has positive impact on } \\
\operatorname{PFD}(\alpha=5 \%)\end{array}$ & $\mathrm{H} 3$ is accepted \\
\hline & & $\begin{array}{c}\text { Gender } \\
\text { Diversity * } \\
\text { X }\end{array}$ & $\begin{array}{c}\text { Ability in Preventing } \\
\text { Financial Distress (PFD) }\end{array}$ & $\begin{array}{c}0.144 \\
(\mathrm{p} \text { value }=0.052)\end{array}$ & $\begin{array}{l}\text { GD serves as moderating } \\
\text { variable to } \operatorname{PFD}(\alpha=10 \%)\end{array}$ & $\begin{array}{c}\text { H4 is accepted } \\
\text { (Quasi } \\
\text { Moderation) }\end{array}$ \\
\hline \multirow{4}{*}{ Malaysia } & $\begin{array}{l}\text { Board Structure } \\
\text { (BS) }\end{array}$ & - & $\begin{array}{c}\text { Ability in Preventing } \\
\text { Financial Distress (PFD) }\end{array}$ & $\begin{array}{c}=0.046 \\
\text { (p value }=0.152)\end{array}$ & BS has no impact on PFD & $\mathrm{Hl}$ is rejected \\
\hline & $\begin{array}{c}\text { Managerial } \\
\text { Ownership (MO) }\end{array}$ & - & $\begin{array}{c}\text { Ability in Preventing } \\
\text { Financial Distress (PFD) }\end{array}$ & $\begin{array}{c}=0.280 \\
\text { (p value }<0.001)\end{array}$ & $\begin{array}{c}\text { MO has negative impact } \\
\text { on } \operatorname{PFD~}(\alpha=5 \%)\end{array}$ & $\mathrm{H} 2$ is accepted \\
\hline & $\begin{array}{c}\text { Gender Diversity } \\
\text { (GD) }\end{array}$ & - & $\begin{array}{c}\text { Ability in Preventing } \\
\text { Financial Distress (PFD) }\end{array}$ & $\begin{array}{c}0.180 \\
(\mathrm{p} \text { value }<0.001)\end{array}$ & $\begin{array}{c}\text { GD has positive impact on } \\
\operatorname{PFD}(\alpha=5 \%)\end{array}$ & $\mathrm{H} 3$ is accepted \\
\hline & & $\begin{array}{c}\text { Gender } \\
\text { Diversity * } \\
\text { X }\end{array}$ & $\begin{array}{c}\text { Ability in Preventing } \\
\text { Financial Distress (PFD) }\end{array}$ & $\begin{array}{c}0.061 \\
(\mathrm{p} \text { value }=0.087)\end{array}$ & $\begin{array}{l}\text { GD serves as moderating } \\
\text { variable to } \operatorname{PFD}(\alpha=10 \%)\end{array}$ & $\begin{array}{c}\text { H4 is accepted } \\
\text { (Absolute } \\
\text { moderation) }\end{array}$ \\
\hline
\end{tabular}

Source: Author's compilation 


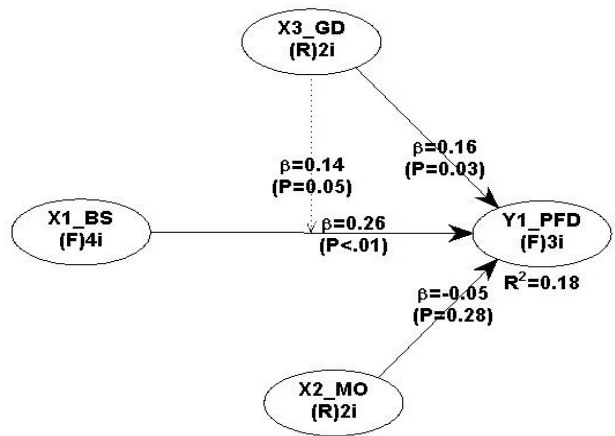

Figure 3. Model Result - Indonesia

Figure 3 above shows the result of Indonesia consumer goods listed companies' direct effect of board structure, managerial ownership and gender diversity to the ability of preventing financial distress with gender diversity as moderating variable after the SEM analysis was completed. The figure above presents the results of path coefficients, $p$ values and R-squared coefficients. Generally, beta coefficient is the value of the path coefficients in PLS-based SEM analysis. Meanwhile, the percentage of variance in the latent variable which is explained by latent variables that are hypothesized to affect it is reflected in R-squared coefficient.

Board structure $(\mathrm{BS})$ has positive impact $(\mathrm{p}<0.05)$ to the ability in preventing financial distress (PFD) with coefficient value of 0.26 . On the other hand, managerial ownership (MO) has no significant impact $(\mathrm{p}>0.05$ as well as $\mathrm{p}>0.10)$ to the ability in preventing financial distress (PFD) as its $p$ value $=0.28$ with coefficient value of 0.05 . Meanwhile, gender diversity (GD) has positive significant impact $(\mathrm{p}<0.05)$ to the ability in preventing financial distress (PFD). Gender diversity has significant level of $<5 \%$ with coefficient value of 0.26 . In addition, gender diversity also serves as moderating variable because there is a significant impact where the significant level is less than $5 \%(\mathrm{p}<0.05)$. The coefficient value of gender diversity as moderating variable is 0.14 . Further, it can be concluded that the type of moderation in Indonesia sample is quasi moderation based on table 3.3. Quasi moderation occurs when $b_{1}, b_{2}$ and $b_{3}$ are significant.

The board structure's result in Indonesia is in accordance with Manzaneque, et al. (2016) who found that board size and board composition is negatively associated with financial distress. For board size, previous research study by Brédart (2014) has also found that board size has negative relationship to financial distress. Hence, higher board size will reduce the likelihood of company experiencing financial distress. Findings in research of Chaganti, et al. (1985) shows that non - failed companies tend to have larger board compared to failed companies. This result also in line with Akhmetova \& Batomunkueva (2014), Elloumi \& Gueyié (2001) and Wang \& Deng (2006) who found that proportion of independence directors on board is negatively related to the probability of financial distress.

For managerial ownership, it is in line with empirical result of Li, et al. (2008) and Wang \& Deng (2006) which indicate that managerial ownership has insignificant effect to the financial distress. This result can be due to small fraction of managerial ownership for both board of directors and board of commissioners in Indonesia (Table 2. shows the mean of managerial ownership at 0.02 for board of directors and 0 for board of commissioners), thus the effect of convergence or entrenchment are limited (Li, Wang, \& Deng, 2008). This is also possible because the shares own by company's management are belong to employee shares which are issued with the aim to add benefits rather than an incentive scheme (Xu \& Wang, 2007 as cited in Wang \& Deng, 2006).

Figure 4 below shows the result of Malaysia consumer goods listed companies' direct effect of board structure, managerial ownership and gender diversity to the ability of preventing financial distress with gender diversity as moderating variable. Board structure has no significant impact $(p>0.05$ as 
well as $\mathrm{p}>0.10)$ to the ability in preventing financial distress. On the other hand, managerial ownership has negative significant impact $(\mathrm{p}<0.05)$ to the ability in preventing financial distress with coefficient value of 0.28 . Contrary to managerial ownership, gender diversity has positive significant impact $(\mathrm{p}<0.05)$ to the ability in preventing financial distress with coefficient value of 0.18 . Furthermore, gender diversity also serves as moderating variables as its significant level is less than $10 \%(\mathrm{p}<0.10)$ with the coefficient value of 0.06 . In addition, it can be concluded that the type of moderation in Indonesia sample is absolute moderation where $b_{1}$ is not significant while $b_{2}$ and $b_{3}$ are significant.

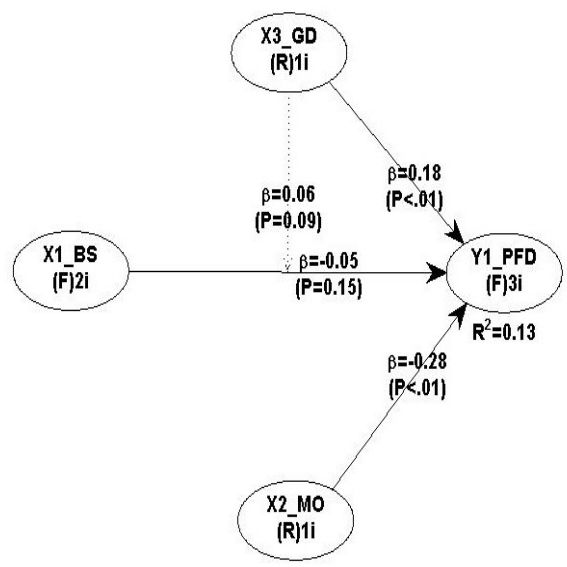

Figure 4. Model Result - Malaysia.

The board structure's result is in line with Shahwan (2015) who found that there is no relationship between corporate governance which is measured by corporate governance index to the probability in financial distress in Egypt. Additionally, previous research studies conducted by Akhmetova \& Batomunkueva (2014) and Wang \& Deng (2006) have found that there is no significant effect between board sizes to the probability of financial distress. Brédart (2014) and Wardhani (2007) also found that board independence has insignificant effect to the financial distress. Furthermore, Malaysia's result is in accordance with stewardship theory. According to stewardship theory, managers are seen as good stewards who eagerly do the job to achieve the high level of profit and shareholder return (Donaldson \& Davis, 1991). Close monitoring and monitoring are less likely to be the focused to the manager's stewardship attitude (Davis, Schoorman , \& Donaldson, 1997). Aside from that, the trade statistic in term of export of goods and services (\% of GDP) in Malaysia for the period of 2011 to 2015 is significantly higher compared to Indonesia (The World Bank, 2015). In 2015, the export of goods and services in Malaysia shows the percentage $70.9 \%$ of GDP (Global Edge, 2017) meanwhile Indonesia's export of goods and services is only $21.09 \%$ of GDP (Global Edge, 2017). It means that the international trade of Malaysia is greater as the percentage of export in Malaysia is high. Therefore, companies will try to maintain their reputation due to their market has expanded to international market. Hence it can be inferred that board structure is not related to the ability in preventing financial distress because corporate governance has become a culture in Malaysia companies.

For managerial ownership, this result contradicts with the results of some researchers ((Manzaneque, Priego, \& Merino, 2016) and (Akhmetova \& Batomunkueva, 2014)). The negative impact in Malaysia sample is occurred due to some reasons. First, there are $66 \%$ sample which are below the mean value of managerial ownership at $15.88 \%$ while the percentage of sample above the average is $34 \%$. It represents that most companies in the data sample do not have high managerial ownership. Second, the average of EBIT as well as average of RE in high managerial ownership sample are lower compared to low managerial ownership sample. The lower average of EBIT indicates that the increase 
in profit is low while lower average of RE means that the increased of past profitability is also low. Moreover, the average of FE is also lower in high managerial ownership which means that the cost of debt is low. In other words, companies with high managerial ownership in Malaysia data sample are less risky rather than companies with low managerial ownership. This result can be also supported by Hofstede Cultural dimension which states that Malaysia is more short-term oriented (Hofstede, 2017). Besides that, the conflict of interest between management, shareholders, investors and debt holders are more serious and intense in financial distress situation compared to normal condition (Donker, Santen, \& Zahir, 2009). Managers choose a short-term strategy and make prejudiced managerial decisions due to the prospect of losing their jobs (Donker, Santen, \& Zahir, 2009). This led to managers' behavior to prioritize their personal gains and interests rather than making value enhancing decisions and maximizing value of company to ensure the company's survival in financial distress.

For both Indonesia and Malaysia, gender diversity's results are in accordance with the research conducted by Kristanti, et al. (2016) who found that gender diversity has an impact to financial distress. According to agency theory, board diversity can enhance the independence on board, thus agency problem in the company can be reduced. Furthermore, gender diversity on board becomes important as it can add value in the companies. Monitoring control in the company will also be improved when the board consists of men and women (Adams \& Ferreira, 2004). Moreover, Carter, et al. (2003) reported that there is a positive relationship between women presence on board and company's performance. Greater diversity also can provide greater innovation, perceptions and flexibility in the decision-making process.

Table 8. Supporting Details for Managerial Ownership in Malaysia Sample

\begin{tabular}{|l|l|l|}
\hline & \multicolumn{1}{|c|}{$\begin{array}{c}\text { Below Mean - Low } \\
\text { Managerial Ownership } \\
(66 \% \text { of total sample) }\end{array}$} & $\begin{array}{c}\text { Above Mean - High } \\
\text { Managerial Ownership } \\
(34 \% \text { of total sample) }\end{array}$ \\
\hline Avg. EBIT & $97,796,290.34$ & $16,244,582.21$ \\
\hline Avg. FE & $8,704,051.94$ & $1,899,701.42$ \\
\hline Average RE & $533,658,842.37$ & $68,316,595.98$ \\
\hline Avg. Total Assetst-1 & $1,070,592,639.70$ & $218,631,252.87$ \\
\hline Avg. Total Debt & $213,712,114.74$ & $40,950,466.40$ \\
\hline Avg. Total Equity & $782,753,130.65$ & $151,780,906.05$ \\
\hline Debt/Equity & $21 \%$ & $21 \%$ \\
\hline
\end{tabular}

Source: Author's compilation

\section{Conclusion}

This study examines the influence of board structures and managerial ownership to identify the potential of financial distress. The board structures are represented by board and executive size and composition, while the board gender diversity is the moderating variable that interact the influences of board structures and managerial ownership toward financial distress. The research objects are companies in consumer goods sector in Indonesia and Malaysia. Mixed results are found in this study. The Board structure has a positive impact to the ability in preventing financial distress in Indonesia, thus the probability of company experiencing financial distress is lower. Meanwhile, there is no impact found in case of Malaysia. In Indonesia, there is no impact found between managerial ownership and ability in preventing financial distress. On contrary, managerial ownership has a negative impact to the ability in preventing financial distress in case of Malaysia companies. Both results of Indonesia and Malaysia shows that gender diversity has positive impact to the ability in preventing financial distress, thus the probability of company experiencing financial distress is lower. Gender diversity as moderating variable in both Indonesia and Malaysia has a positive impact to the 
ability in preventing financial distress. The positive impact implies that gender diversity is able to strengthen the impact of board structure to the ability in preventing financial distress.

Board structures show mixed results in Indonesia and Malaysia. For companies in Indonesia, it is found that board structure has an impact to the ability in preventing financial distress. Higher board structures lead to higher ability in preventing financial distress. Meanwhile, the finding in Malaysia data found that there is no significant impact between board structure and ability in preventing financial distress. Large board size can give companies more knowledge, expertise, skills and external links which can be useful in financial distress situation, however large board size may also be less effective and time - consuming. Therefore, companies should find and maintain the right balance of board structure whether in terms of board size or board composition in order to maximize the ability in preventing financial distress. The number of members on board can be varied depend on company's necessities and complexity of its business. Jensen (1993) explained that the board function will be more effective when the number of boards in the company is less than 7 (seven) to 8 (eight) members. A study (Lipton \& Lorsch, 1992) suggests the maximum number of members on board is from 8 (eight) to 10 (ten), otherwise it will be less effective in terms of expressing ideas and opinions in limited time.

Gender diversity in both Indonesia and Malaysia has positive impact to the ability in preventing financial distress. Furthermore, gender diversity also serves as moderating variable in both countries. Aside it indicates that proportion on women and men on board are important, it also shows that gender diversity can strengthen the impact of board structure to the ability in preventing financial distress. Hence, companies should consider and maintain gender diversity on its board as gender diversity has its advantages toward company's performance and ability in preventing financial distress.

Besides that, the company's management is encouraged to enrich their knowledge in corporate governance mechanism in order to gain a better understanding about the impact of corporate governance and ability in preventing financial distress. This better understanding can help the company to overcome and manage the company's survival in financial distress situation. The limitation in this research is the average adjusted R-squared of Indonesia and Malaysia which are $14.9 \%$ and $12.5 \%$ respectively. These results indicate that the model of this research study has a very low explanatory power. In addition, the goodness of fit test criteria of GoF in Indonesia and Malaysia show a medium range. Hence, more corporate governance components or other variables, such as control variable can be added in the future research. Besides that, this research only examines Indonesia and Malaysia companies in consumer goods sector, thus all sectors in manufacturing industry or all registered companies in Indonesia Stock Exchange and Bursa Malaysia can be examined as the object for further research study.

\section{References}

Adams, R. B. \& Ferreira, D. (2004). Gender Diversity in the Boardroom. ECGI Working Paper Series in Finance 58.

Adams, R. B. \& Ferreira, D. (2009). Women in the boardroom and their impact on governance and performance. Journal of Financial Economics 94(2), 291 - 309.

Akhmetova, A. \& Batomunkueva, Y. (2014). Board Composition and Financial Distress: An empirical evidence from Sweden and Denmark. Master's thesis, Umea School of Business and Economics.

Appuhami, R. \& Bhuyan, M. (2015). Examining the Influence of Corporate Governance on Intellectual Capital Efficiency. Managerial Auditing Journal, 30(4/5), 347-372.

Badan Pusat Statistik. (2017). Badan Pusat Statistik. [Online]. Available at: https://www.bps.go.id/linkTableDinamis/view/id/828. [Accessed 4 April 2017].

Brédart, X. (2014). Financial Distress and Corporate Governance: The Impact of Board. International Business Research, 7(3) 
Brigham, E. F. \& Daves, P. R. (2007). Intermediate Financial Management. 9th ed. USA: Thomson South-Western.

Campbell, K. \& Minquez-Vera, A. (2008). Gender Diversity in the Boardroom and Firm Financial Performance. Journal of Business Ethics, 435 - 451.

Carter, D. A., Simkins, B. J. \& Simpson, W. G. (2003). Corporate Governance, Board Diversity, and Firm Value. The Financial Review 38, 33 - 53.

Catalyst. 2007. Catalyst. [Online]. Available at: http://www.catalyst.org/knowledge/bottom-linecorporate-performance-and-womens-representation-boards. [Accessed 27 April 2017].

Chaganti, R. S., Mahajan, V. \& Sharma, S., 1985. Corporate Board Size, Composition and Corporate Failures in Retailing Industry. Journal of Management Studies, 22(4), 400 - 417.

Claessens, S., Djankov, S. \& Klapper, L., 2003. Resolution of corporate distress in East Asia. Journal of Empirical Finance 10,199-216.

Daily, C. M., Dalton, D. R. \& Cannella Jr, A. A., 2003. Corporate Governance: Decades of Dialogue and Data. The Academy of Management Review, 28(3), 371 - 382.

Darmadi, S., 2013. Do women in top management affect firm performance? Evidence from Indonesia. The International Journal of Business in Society, 288 - 304.

Davis, J. H., Schoorman , F. D. \& Donaldson, L. (1997). Toward A Stewardship Theory of Management. Academy of Management Review, 22(1), 20 - 47.

Department of Statistics Malaysia. (2017). Gross Domestic Product Fourth Quarter 2016. [Online]. Available

at: https://www.dosm.gov.my/v1/index.php?r=column/cthemeByCat\&cat=100\&bul_id=aG1XU T10YmhLQjYvR01kWXp4V3ZWUT09\&menu_id=TE5CRUZCblh4ZTZMODZIbmk2aWR RQT09. [Accessed 5 April 2017].

Donaldson, L. \& Davis, J. H. (1991). Stewardship Theory or Agency Theory: CEO Governance and Shareholder Returns. Australian Journal of Management, 49 - 65.

Donker, H., Santen, B. \& Zahir, S. (2009). Ownership structure and the likelihood of financial distress in the Netherland. Applied Financial Economics, 19, 1687-1696.

Elloumi, F. \& Gueyié, J. P. (2001). Financial distress and corporate governance: an empirical analysis. Corporate Governance: The International Journal of Business in Society, 1(1), 15-23.

Fama, E. F. \& Jensen, M. C. (1983). Separation of Ownership and Control. Journal of Law and Economics, 26(2), $301-325$.

Fich, E. M. \& Slezak, S. L. (2008). Can corporate governance save distressed firms from bankruptcy? An empirical analysis. Review of Quantitative Finance and Accounting 30, 225 - 251.

Global Edge. (2017). Global Edge. [Online]. Available at: https://globaledge.msu.edu/countries/indonesia/tradestats. [Accessed 12 June 2017].

Global Edge. (2017). Malaysia: Trade Statistics. [Online]. Available at: https://globaledge.msu.edu/countries/malaysia/tradestats. [Accessed 12 June 2017].

Hofstede. (2017). Geert Hofstede. [Online]. Available at: https://www.geerthofstede.com/indonesia.html

Hofstede. 2017. Malaysia. [Online]

Available at: https://geert-hofstede.com/malaysia.html

International Finance Corporation Advisory Services in Indonesia. (2014). The Indonesia Corporate Governance Manual. 1st ed. Jakarta: s.n.

International Finance Corporation Advisory Sevices in Indonesia. (2014). The Indonesia Corporate Governance Manual. 1st ed. Jakarta: s.n.

Isidro, H. \& Sobral, M. (2015). The Effects of Women on Corporate Boards on Firm Value, Financial Performance, and Ethical and Social Compliance. J Bus Ethics, 1 - 19.

Jensen, M. C. (1993). The Modern Industrial Revolution, Exit, and the Failure of Internal Control Systems. The Journal of Finance, 48(3), 831-880. 
Jensen, M. C. \& Meckling, W. H. (1976). Theory of the Firm: Managerial Behavior, Agency Costs and Ownership Structure. Journal of Financial Economics, 3(4), 305 - 360.

Kamardin, H. \& Haron, H. (2011). Internal corporate governance and board performance in monitoring roles: Evidence from Malaysia. Journal of Financial Reporting and Accounting, 9(2), 119-140.

Komite Nasional Kebijakan Governance. (2006). Pedoman Umum Good Corporate Governance Indonesia. s.l.:s.n.

Kristanti, F. T., Rahayu, S. \& Huda, A. N. (2016). The Determinant of Financial Distress on Indonesian Family Firm. Procedia-Social and Behavioral Sciences.

Lakshan, A. M. I., \& Wijekoon, W. M. H. N. (2012). Corporate governance and corporate failure. Procedia Economics and Finance, 2(2012), 191-198.

Li, H. X., Wang, Z. J. \& Deng, X. L. (2008). Ownership, independent directors, agency costs and financial distress: evidence from Chinese listed companies. Corporate Governance: The International Journal of Business in Society, 8(5), 622 - 636.

Lipton, M. \& Lorsch, J. W. (1992). A Modest Proposal for Improved Corporate Governance. The Business Lawyer, 48(1), 59 - 77.

Manzaneque, M., Priego, A. M. \& Merino, E. (2016). Corporate governance effect on financial distress likelihood: Evidence from Spain. Spanish Accounting Review, 19 (1), 111-121.

McGee, R. W. (2008). Corporate Governance in Asia: A Comparative Study of Indonesia, Malaysia, Thailand and Vietnam. Working Paper.

Pearce, J. \& Zahra, S. (1992). Board compesation from a strategic contigency perspective. Journal of Management Studies, 18, 411 - 438.

Pindado, J., Rodriguesb, L. \& De La Torre, C. (2008). Estimating the Probability of Financial Distress: International Evidence. Journal of Business Research, 61, 995-103.

PWC. (2015). 2015-15 Outlook for the Retail and Consumer Products Sector in Asia, s.l.: s.n.

Rajablu, M. (2016). Corporate governance: a conscious approach for Asia and emerging economies. International Journal of Law and Management, 58(3), 317 - 336.

Salloum, C., Bouri, E. \& Schmitt, C. (2013). Board of directors and financial performance in the Middle East. Int. J. Business Performance Management, 14(3), 274 - 292.

Securities Commission Malaysia. (2012). Malaysia code on corporate governance 2012. 1 - 43.

Securities Commission Malaysia. (2016). Proposed Draft of Malaysian Code on Corporate Governance 2016. Public Consultation Paper, 1 - 25.

Shahwan, T. M. (2015). The effects of corporate governance on financial performance and financial distress: evidence from Egypt", Corporate Governance. Corporate Governance, 641 -662.

The World Bank. (2015). Exports of goods and services (\% of GDP). [Online]

Available at: http://data.worldbank.org/indicator/NE.EXP.GNFS.ZS?end=2015\&locations=IDMY\&start $=2010$

[Accessed 12 June 2017].

Wahab, E. A. A., Pitchay, A. . A. \& Ali, R. (2015). Culture, corporate governance and analysts forecast in Malaysia. Asian Review of Accounting, 23(3), 206 - 231.

Wang, Z. J. \& Deng, . X. L. (2006). Corporate Governance and Financial Distress: Evidence from Chinese Listed Companies. The Chinese Economy, 39(5), 5-27.

Wardhani, R. (2007). Mekanisme Corporate Governance dalam Perusahaan yang Mengalami Permasalahan Keuangan. Jurnal Akuntansi dan Keuangan Indonesia, 4(1), 95 - 114.

World Bank. (2010). Indonesia - Report on the Observance of Standards and Codes (ROSC): Corporate Governance Country Assessment. [Online]. Available at: http://documents.worldbank.org/curated/en/514561468039867553/Indonesia-Report-on-theObservance-of-Standards-and-Codes-ROSC-corporate-governance-country-assessment

Yermack, D. (1996). Higher market valuation of companies with a small board of directors. Journal of Financial Economics, 40, 185 - 211. 